\title{
The spider genus Medionops Sánchez-Ruiz \& Brescovit (Araneae: Caponiidae) in Colombia, with the description of four new species
}

\author{
Leonel MARTÍNEZ ${ }^{\circledR 1}$, Alexander SÁNCHEZ-RUIZ ${ }^{\oplus_{2, *}}$ \& Alexandre B. BONALDO ${ }^{\oplus_{3}}$ \\ ${ }^{1}$ Grupo de Investigación Biodiversidad del Caribe Colombiano, Semillero de Investigación Sistemática \\ de Artrópodos Neotropicales, Departamento de Biología, Universidad del Atlántico, Barranquilla, \\ Colombia. \\ ${ }^{2,3}$ Museu Paraense Emílio Goeldi, Coordenação de Zoologia, Laboratório de Aracnologia, \\ Av. Perimetral, 1901, Terra Firme, CEP 66077-830, Belém, Pará, Brazil. \\ *Corresponding author: alex.sanchezruiz@hotmail.com \\ ${ }^{1}$ Email: leonelmarbio@gmail.com \\ 33Email: bonaldo@museu-goeldi.br \\ ${ }^{1}$ urn:1sid:zoobank.org:author:C3E9FDB9-4381-4ED3-AB0C-6C7F739CCCED \\ ${ }^{2}$ urn:lsid:zoobank.org:author:D312037D-5F2B-4F86-A822-F0BAD1BEF20A \\ ${ }^{3}$ urn:1sid:zoobank.org:author:118CFCBA-BD7E-4F15-8412-4979159298BA
}

\begin{abstract}
Four new Colombian species of the spider genus Medionops Sánchez-Ruiz \& Brescovit, 2017 are described and illustrated: M. carolinae sp. nov. (male and female) from Boyacá department, M. cauca sp. nov. (male) from Cauca department, M. luiscarlosi sp. nov. (male and female) from Caldas department and M. santarosa sp. nov. (male) from Risaralda department. Additionally, the distribution of the type species of M. blades Sánchez-Ruiz \& Brescovit, 2017, previously known only from Bogotá, Cundinamarca department, is extended to several localities in the Boyacá department. An updated identification key for all Medionops species is provided.
\end{abstract}

Keywords. Arachnida, Synspermiata, Nopinae, taxonomy, Neotropical region.

Martínez L., Sánchez-Ruiz A. \& Bonaldo A.B. 2021. The spider genus Medionops Sánchez-Ruiz \& Brescovit (Araneae: Caponiidae) in Colombia, with the description of four new species. European Journal of Taxonomy 773: 61-79. https://doi.org/10.5852/ejt.2021.773.1511

\section{Introduction}

The family Caponiidae Simon, 1890 is an unusual group of ground-wandering spiders, commonly found under rocks, tree trunks and leaf litter. Currently, it is represented by 19 genera and 127 species (World Spider Catalog 2021) occurring in America, Africa and Asia. The generic and specific diversity of the family is certainly great in the New World, where 108 species (15 genera) are known; while only 16 species (two genera) occur in Africa, a single monotypic genus is recorded in Iran and only two species (one genus) are known from Southeast Asia (World Spider Catalog 2021). The Caponiidae are 
divided into two subfamilies according to Petrunkevitch (1939): Nopinae, a subfamily exclusive to the New World and probably a monophyletic lineage, which includes those genera with tarsi divided by one or more adesmatic joints (Sánchez-Ruiz \& Brescovit 2018), and Caponinae including all other nonnopine genera.

The Nopinae genus Medionops Sánchez-Ruiz \& Brescovit, 2017 was proposed by Sánchez-Ruiz \& Brescovit (2017) for seven species distributed in Trinidad, Panama, Colombia, Ecuador, Venezuela and Brazil. Members of this genus are characterized by having all legs with an elongated and dorsally reflexed unpaired claw, associated with a large and globose arolium (Sánchez-Ruiz \& Brescovit 2017). Previous studies of pretarsal morphology in Medionops by Sánchez-Ruiz \& Brescovit $(2017 ; 2018)$ suggest that the genus is closely related to Nops MacLeay, 1839 and Nopsides Chamberlin, 1924, since some characteristics, such as the elongated unpaired claws and the presence of an arolium, are exclusive to these three genera.

The discovery of Medionops by Sánchez-Ruiz \& Brescovit (2017) was based on the examination of specimens gathered for the revision of Nops, published by Sánchez-Ruiz \& Brescovit (2018). Specimens from 30 caponiid collections around the world were examined for the Nops revision, nine of which containing specimens later described as Medionops, many of them even identified and labeled as Nops at that time.

Despite the fairly large sample of Caponiidae examined by Sánchez-Ruiz \& Brescovit (2017, 2018), only a few dozen Colombian specimens came to light, none belonging to Colombian collections. As a result, no additional Colombian specimens were revised in either of these two studies. The scarce material reviewed from Colombia led to the fact that, till now, only one species of Nops (N. variabilis Keyserling, 1877) and one species of Medionops (M. blades Sánchez-Ruiz \& Brescovit, 2017) were recorded from Colombia.

Recent examination of material from a Colombian arachnological collection (Instituto Alexander Von Humboldt), allowed the discovery of four undescribed Medionops species. These species are herein described and new distribution records for M. blades are given based on material also found in this arachnological collection. A detailed description of somatic and genitalic characteristics, images of the habitus, male palpal morphology and female genital organs, line drawings of the male copulatory bulbs and a distribution map for all Colombian species are provided. Additionally, an updated identification key for all species of the genus is presented.

\section{Material and methods}

Morphological observations and illustrations were made using a Leica MC125 stereo microscope with a camera lucida. Multifocal images were taken with Leica MC-190 HD and Leica MC-170 HD digital cameras attached to Leica S8AP0 and Leica MC125 stereo microscopes, respectively, with extended focal range. All multifocal images were assembled using Helicon Focus Pro ver. 5.3.14. Measurements are provided in millimeters $(\mathrm{mm})$ and were made using an ocular micrometer. Descriptions and measurements follow Sánchez-Ruiz \& Brescovit (2017). Coloration patterns were described based on specimens preserved in 70-80\% ethanol. All type specimens are in good conditions of preservation; the left male palp and female internal genitalia of holotypes and paratypes were dissected for detailed examination and documentation and stored in microvials inside their respective vials. The terminology for copulatory structures follows Sánchez-Ruiz et al. (2015). For M. blades, the female genitalia were dissected with fine forceps and scalpel and their soft tissues were digested for 24 hours within a solution of pancreatin following Álvarez-Padilla \& Hormiga (2007). For the remaining species the female genitalia were extracted in the same way but digested with Ultrazime ${ }^{\circledR}$ contact lens cleaner enzyme (1 tablet $/ 5 \mathrm{ml}$ distilled water). 
The digital photos were edited using Adobe Photoshop ${ }^{\circledR}$ CS ver. 12.0 and figures were edited with Corel Draw ${ }^{\circledR}$ X7 ver. 17.1. Maps were prepared in QGIS (QGIS Development Team 2021). All locality coordinates were obtained from specimen labels and converted to the DMS format (degrees, minutes and seconds). Locality elevations refer to meters above sea level in all cases.

\section{Institutional abbreviations}

$\mathrm{IAvH}=$ Instituto Alexander Von Humboldt (curator: J.C. Neita), Bogotá, Colombia $\mathrm{AMNH}=$ American Museum of Natural History (curator: L. Prendini), New York, USA

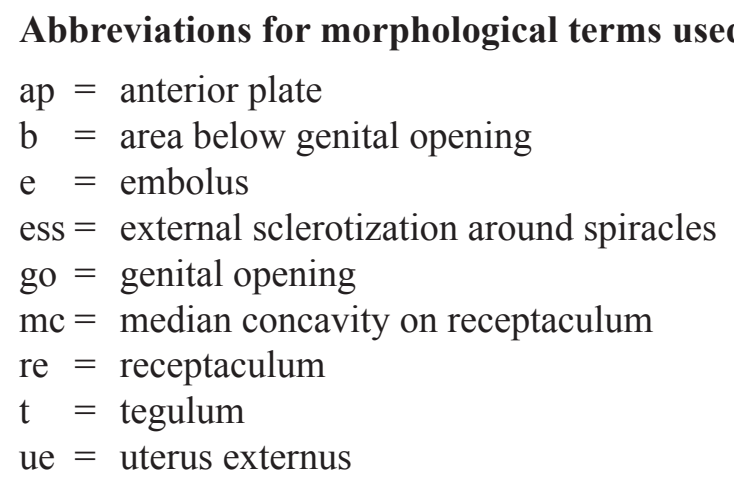

\section{Results}

Taxonomy

Class Arachnida Cuvier, 1812

Order Araneae Clerck, 1757

Family Caponiidae Simon, 1890

Genus Medionops Sánchez-Ruiz \& Brescovit, 2017

Updated key to the species of Medionops Sánchez-Ruiz \& Brescovit, 2017

1. Abdomen dorsally with remarkable pattern of gray chevrons or stains (Figs 1A, C, 2A, C, 3A) .... 2

- Abdomen dorsally with unremarkable pattern of very fine gray chevron lines, almost unnoticeable (Sánchez-Ruiz \& Brescovit 2017: figs 17a-b, 20a) ..... 10

2. Abdomen dorsally with five pairs of irregular dark gray stains forming two longitudinal bands (Sánchez-Ruiz \& Brescovit 2017: figs 18a-b, 10a) ....

- Abdomen dorsally with five whitish gray chevron stripes, which decrease in size towards the posterior part of abdomen (Figs 1A, C, 2A, C, 3A)

3. Dorsal irregular dark gray stains on abdomen very close to each other, almost touching (Sánchez-Ruiz \& Brescovit 2017: fig. 18a-b); crista very short; body more than $5 \mathrm{~mm}$ total length M. simla (Chickering, 1967)

- Dorsal irregular dark gray stains on abdomen widely separated from each other, not touching (Sánchez-Ruiz \& Brescovit 2017: fig. 10a); crista absent (Sánchez-Ruiz \& Brescovit 2017: fig. 9k); body less than $3 \mathrm{~mm}$ total length M. claudiae Sánchez-Ruiz \& Brescovit, 2017

4. Gladius absent (Sánchez-Ruiz \& Brescovit 2017: figs 11c-d, F, 13b-c)

- Gladius present (Dupérré 2014: fig.4; Sánchez-Ruiz \& Brescovit 2017: figs 3g, 9k, 15e) 5 
5. Crista short but noticeable (Sánchez-Ruiz \& Brescovit 2017: fig. 3g, j), reaching at least $1 / 4$ or $1 / 5$ of metatarsal length

- Crista unnoticeable (Sánchez-Ruiz \& Brescovit 2017: fig. 15e-f), only $1 / 6$ or less of metatarsal length, or absent

6. Males embolus tip with several blade-shaped projections (Sánchez-Ruiz \& Brescovit 2017: fig. 2j1); female posterior plate with internally projected median septum (Sánchez-Ruiz \& Brescovit 2017: fig. $4 \mathrm{j}-1)$. M. blades Sánchez-Ruiz \& Brescovit, 2017

- Males with smooth embolus tip, without projections (Sánchez-Ruiz \& Brescovit 2017: fig. 7d-e); female posterior plate without internally projected median septum (Sánchez-Ruiz \& Brescovit 2017: fig. $7 \mathrm{~g}-\mathrm{i}$ )

M. cesari (Dupérré, 2014)

7. Abdomen dorsally with pattern of five large, wide whitish gray chevrons, which reach the lateral whitish gray spots (Figs 2A, C, 3A), ventrally with a pair of longitudinal stripes occupying only the posterior third of the abdomen (Figs 2B, D, 3B); males with bulb greater than patella length (Fig. 2E-F) .....

- Abdomen dorsally with pattern of five small, narrow whitish gray chevrons, that never reach the lateral whitish gray spots (Figs 4A, C, 5A), ventrally without a pair of longitudinal stripes (Figs 4B, D, 5B); males with bulb equal to or smaller than the patella length (Fig. 4E-F)

8. Embolus slightly curved anteriorly, tip with accentuated curvature (Fig. 2E-F)

.M. carolinae sp. nov. (only males)

- Embolus strongly angled at base and slightly sinuous (Figs 3C-D, 7C), tip almost straight (Fig. 3CD) ... cauca sp. nov. (only males)

9. Embolus more than $3 \times$ the maximum tegular width, tip pointed (Fig. 4E-F) .

- Embolus less than $3 \times$ the maximum tegular width, tip truncated (Fig. $5 \mathrm{C}-\mathrm{D}$-D)

M. luiscarlosi sp. nov. (only males)

M. santarosa sp. nov. (only males)

10. Crista short but noticeable, not reaching one fourth of metatarsal length; body more than $4.5 \mathrm{~mm}$ total length; males withembolus lengthmore than $3 \times$ themaximum diameter of the tegulum(Sánchez-Ruiz\& Brescovit 2017: fig. 19g-h), known only from Venezuela M. tabay Sánchez-Ruiz \& Brescovit, 2017

- Crista unnoticeable (Sánchez-Ruiz \& Brescovit 2017: fig. 15d-f); body less than $3.5 \mathrm{~mm}$ total length; males with embolus length over less than $3 \times$ the maximum diameter of the tegulum (Sánchez-Ruiz \& Brescovit 2017: fig. 16a-b), known only from southeast coast of Brazil

..M. ramirezi Sánchez-Ruiz \& Brescovit, 2017

Medionops blades Sánchez-Ruiz \& Brescovit, 2017

Figs 1, 6, 7A, 8A-B

Medionops blades Sánchez-Ruiz \& Brescovit 2017: 122, figs 1e, 2a-1, 3a-1, 4a-1, 5a-1, 6a-e (†đ̂).

Medionops blades - Sánchez-Ruiz, Brescovit \& Bonaldo 2020: 485, fig. 19e (ô).

\section{Diagnosis}

Males resemble those of $M$. carolinae sp. nov. in having similar copulatory bulb shape, but can be distinguished by the straighter embolus tip and by the size of the tegulum, only $1 / 2$ as long as the cymbium length (Figs 1E-F, 7A) (in M. carolinae sp. nov., only $1 / \frac{1}{3}$ as long, Figs $2 \mathrm{E}-\mathrm{F}, 7 \mathrm{~B}$ ). Females of M. blades 
differ from those of M. carolinae sp. nov. by the wide, concave area below the genital opening (Fig. 1G) (in M. carolinae sp. nov., narrower and triangular, Fig. 2G).

\section{Material examined}

Holotype

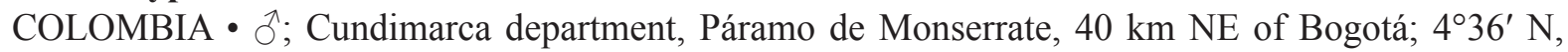
74³' W; alt. 2920 m; 23 Jul. 1968; H. Sturm leg.; AMNH.

\section{Paratype}

COLOMBIA • 1 क ; same collection data as for holotype; AMNH.

\section{Additional material}

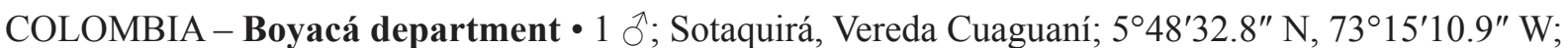
alt. 3502 m; 8-10 Jun. 2015; Y. Cifuentes and J. Moreno leg.; IAvH-I 3381 • 1 ; ; Paipa, Parque

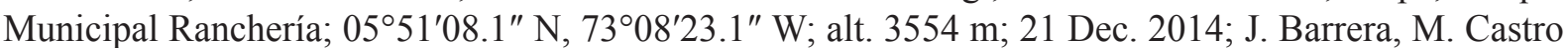

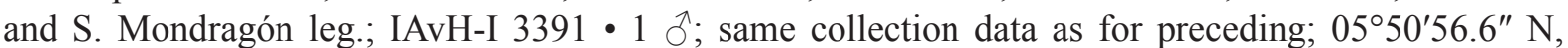

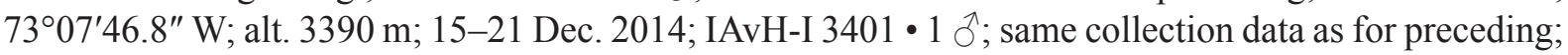

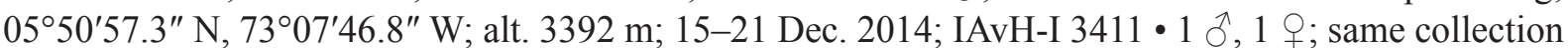
data as for preceding; IAvH-I $3382 \cdot 1$; ; Chaina, Santuario de Flora y Fauna Iguaque, Sector Chaina;

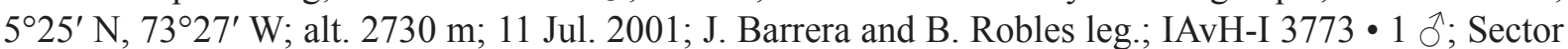

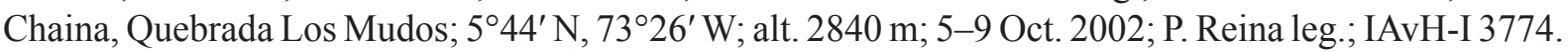

\section{Natural history}

The holotype was found in the Andean moorland complex of the eastern hills of Colombia (Fig. 8A-B) which is predominantly populated by plant species such as Espeletia grandiflora Humb. \& Bonpl. and Cupressus sp.

\section{Description}

Male and female described by Sánchez-Ruiz \& Brescovit (2017).

\section{Variation}

Males from the Boyacá department population (Fig. 1A-B) have the embolus tip somewhat more curved than those from Cundinamarca department (see images from types in Sánchez-Ruiz \& Brescovit 2017: figs $2 \mathrm{~h}, 6 \mathrm{~d}$ ). Females from the Boyacá population (Fig. 1G) have a narrower and more sclerotized area under the genital opening than those from the Cundinamarca population.

\section{Distribution}

Known from Cundinamarca and Boyacá in Colombia (Fig. 6).

Medionops carolinae sp. nov. urn:1sid:zoobank.org:act:CD71F419-D3D8-4CED-AD43-08785FB0C57D

Figs 2, 6, 7B, 8C-F

\section{Diagnosis}

Males resemble those of $M$. blades in having a similar copulatory bulb shape, but can be distinguished by the accentuate curvature on the embolus tip (straighter in M. blades) and by the tegulum $1 / 2$ as long as the cymbium (Figs 2E-F, 7B) ( $1 / 2$ as long in M. blades, Figs 1E-F, 7A). Females of M. carolinae sp. nov. 

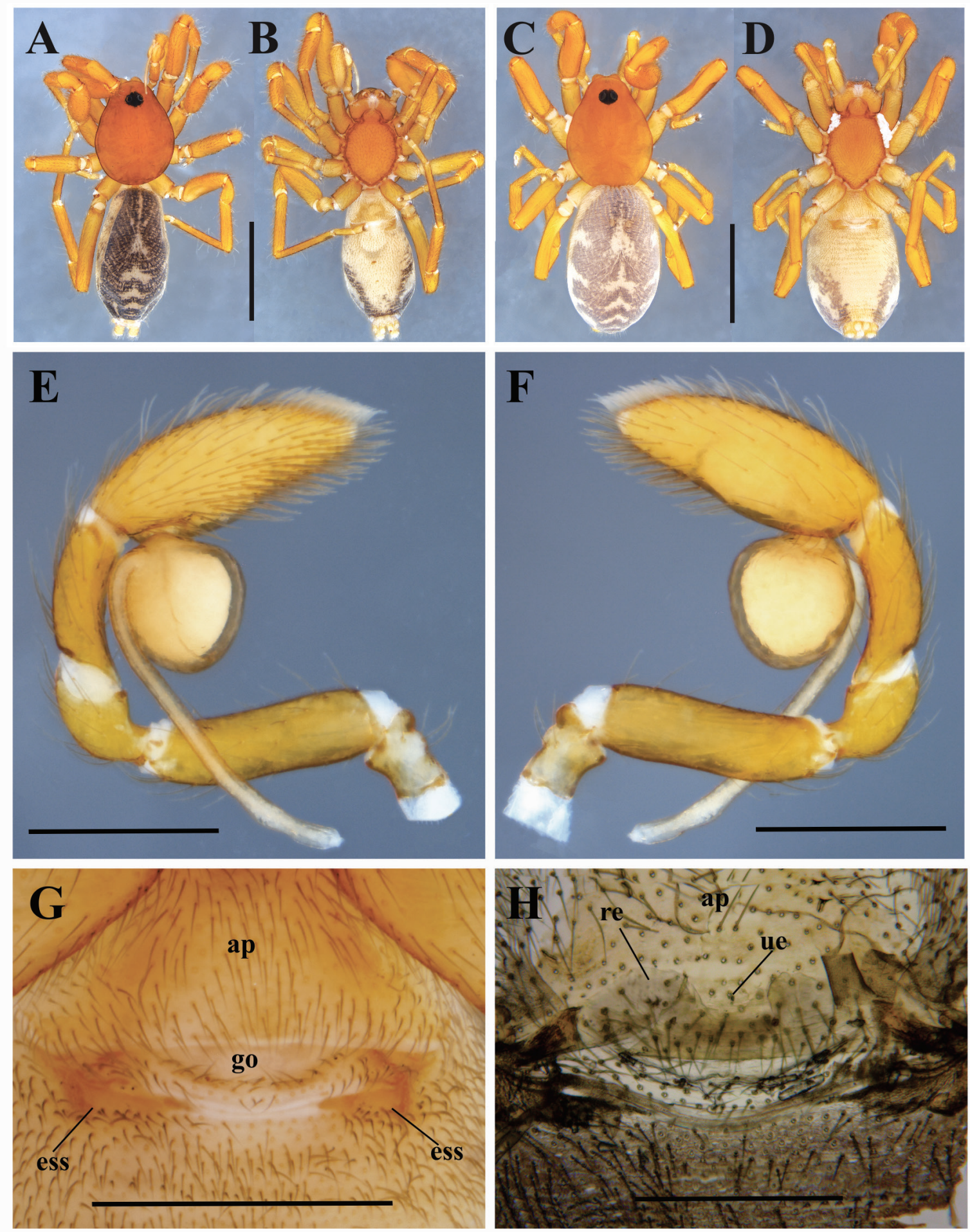

Fig. 1. Medionops blades Sánchez-Ruiz \& Brescovit, 2017. A-B, E-F. Male, Boyacá population (IAvH-I 3381). C-D, G-H. Female, Boyacá population (IAvH-I 3382). A. Habitus, dorsal view. B. Habitus, ventral view. C. Habitus, dorsal view. D. Habitus, ventral view. E. Left palp, retrolateral view. F. Left palp, prolateral view. G. External genitalia, ventral view. H. Internal genitalia, dorsal view. Scale bars: A-D $=1.5 \mathrm{~mm} ; \mathrm{E}-\mathrm{F}=0.7 \mathrm{~mm} ; \mathrm{G}=0.5 \mathrm{~mm} ; \mathrm{H}=0.2 \mathrm{~mm}$. Abbreviations: ap = anterior plate; ess $=$ external sclerotization around spiracles; go $=$ genital opening; re $=$ receptaculum; ue $=$ uterus externo. 
differ from those of $M$. blades by the narrow, triangular area below the genital opening (Fig. 2G) (wider and concave in M. blades, Fig. 1G).

\section{Etymology}

The specific name is a patronym in honor of Carolina Gomez, director of the collections of the Institute Alexander Von Humboldt, Bogotá, Colombia.

\section{Type material}

Holotype

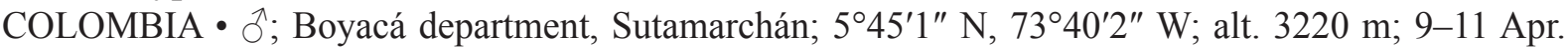
2003; E. González and C. Reina leg.; IAvH-I 3782.

\section{Paratypes}

COLOMBIA - Boyacá department • 1 đ̊; same collection data as for holotype; IAvH-I 3781 • 1 O ; Sector Carrizal, Santuario de Flora y Fauna Iguaque; 5 $42^{\prime} 13^{\prime \prime}$ N, $73^{\circ} 27^{\prime} 18^{\prime \prime}$ W; alt. 2910 m; 4-11 Nov. 2006; J. Arias and P. Delgado leg.; IAvH-I 3771 • 1 今'; Arcabuco, Vereda Rupavita; 544'26.5" N, 73²3'2.3" W; alt. 3340 m; 25-27 Fev. 2015; Y. Cifuentes and D. Espejo leg.; IAvH-I 3343.

\section{Description}

Male (holotype, Figs 2A-B, E-F, 7B)

Measurements. Total length 4.94. Carapace 2.01 long, 1.49 wide. Sternum 1.23 long, 1.02 wide. Legs: I: 4.61; II: 4.59; III: 3.91; IV: 5.82 .

Coloration. Carapace, chelicerae, sternum, labium and endites reddish (Fig. 2A-B). Palps and legs light orange. Abdomen dorsally dark gray with dorsal pattern formed by five wide light chevron stripes, medially joined by thin longitudinal band; ventrally whitish gray (Fig. 2A-B).

LEGS AND PALPS. Crista absent or unnoticeable; gladius with common nopine shape. Palp with small globose tegulum and embolus slightly curved anteriorly, tip with accentuated curvature with subdistal modification and beveled opening (Figs 2E-F, 7B, G).

Female (paratype, Fig. 2C-D, G-H)

Measurements. Total length 5.91. Carapace 2.11 long, 1.74 wide. Sternum 1.33 long, 1.08 wide. Legs: I: 5.01; II: 4.36; III: 3.51; IV: 5.74.

Coloration. As in the male (Fig. 2C-D).

GenitaLIA. External genitalia with narrow, triangular area below genital opening (Fig. 2G); internal genitalia not studied (internal membranous structures completely destroyed during enzymatic digestion, Fig. 2H).

\section{Variation}

Males $(\mathrm{n}=3)$ : total length: 4.72-4.94; carapace length: 2.01-2.05.

\section{Natural history}

All types were collected with pitfall traps baited with human excrement, used to collect dung beetles and ants, mainly in frailejón plants (Espeletia grandiflora Humb. \& Bonpl.) and grassland. Specimens belonging to ant-eating spiders such as Zodariidae Thorell, 1881 were collected together with Medionops in large numbers, probably due to the high availability of prey. Aspects on the natural history of Nopinae spiders are poorly known and only a few studies on the trophic specialization of Nops have been done (see 

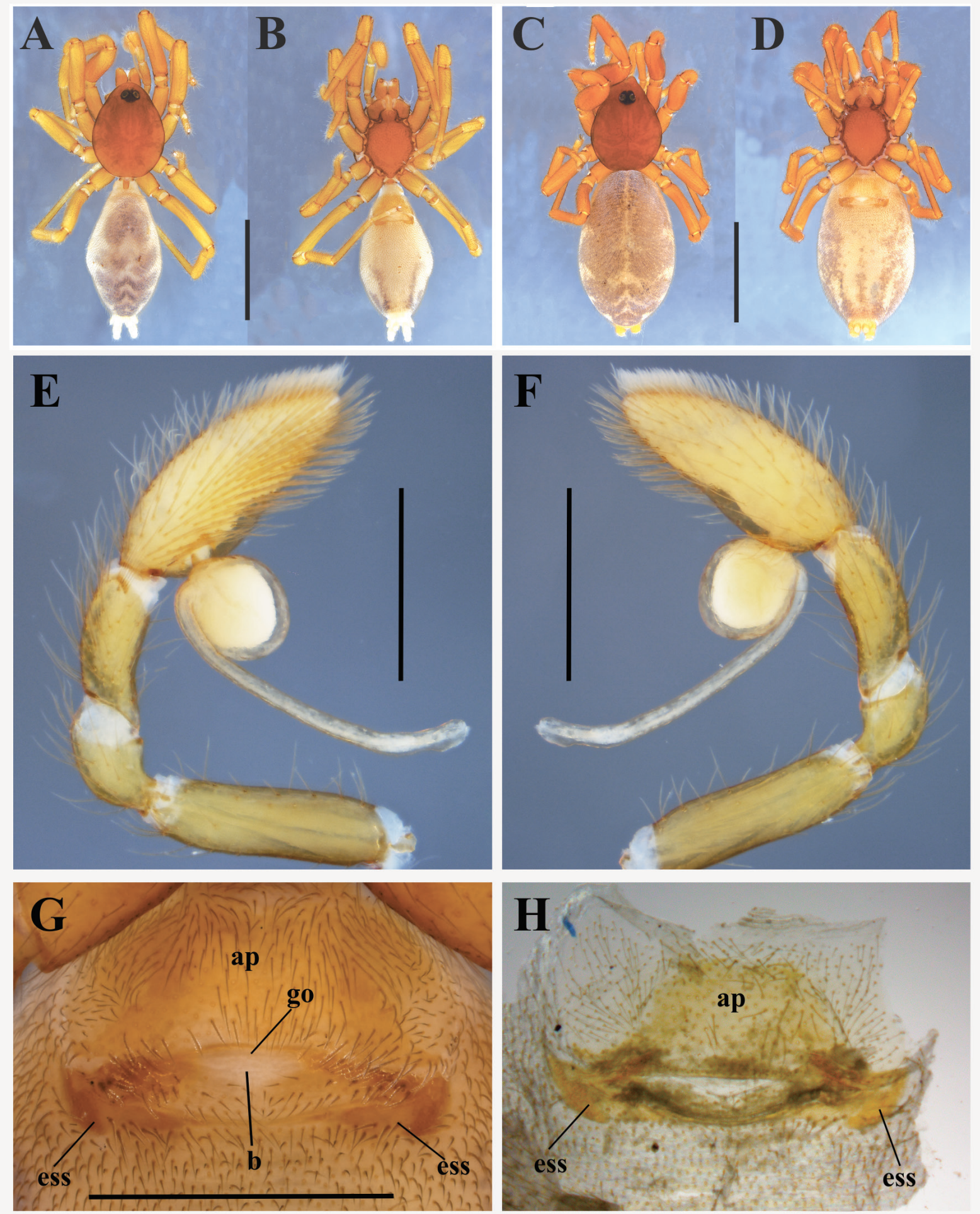

Fig. 2. Medionops carolinae sp. nov. A-B, E-F. Holotype, § (IAvH-I 3782). C-D, G-H. Paratype, $q$ (IAvH-I 3771). A. Habitus, dorsal view. B. Habitus, ventral view. C. Habitus, dorsal view. D. Habitus, ventral view. E. Left palp, retrolateral view. F. Left palp, prolateral view. G. External genitalia, ventral view. H. Internal genitalia, dorsal view. Scale bars: $A-D=1.5 \mathrm{~mm}$; $E-F=0.7 \mathrm{~mm} ; G=0.5 \mathrm{~mm}$; $\mathrm{H}=0.2 \mathrm{~mm}$. Abbreviations: $\mathrm{ap}=$ anterior plate; $\mathrm{b}=$ area below genital opening; ess $=$ external sclerotization around spiracles; go $=$ genital opening. 
García et al. 2018; Teruel \& Sánchez-Ruiz 2000). These studies highlight the remarkable preference of some nopine species for feeding on arachnids (little scorpions and other spiders). Although no detailed studies have been conducted, the adhesive membranous structures (crista and gladius) on the first two pairs of nopine legs are pobably involved in the prey capture process.

\section{Distribution}

Known only from Boyacá department, Colombia (Fig. 6).

\section{Remarks}

The holotype was found in a high Andean humid forest (Fig. 8C-D) and the female paratype was found in a protected area (Sanctuary of Flora and Fauna Iguaque) where human intervention is limited (Fig. 8E-F). The record of this female specimen is separated by only $24 \mathrm{~km}$ from the type locality and $8 \mathrm{~km}$ from the most distant examined specimen located outside the type locality. The height above sea level between type and female localities hardly differs by about $300 \mathrm{~m}$ and even the environments are very similar in both locations (Fig 8C-F). We tentatively matched this female with males from the type locality by similarities in the coloration pattern, but confirmation of this association will be possible only when more samples come to light. We believe that proposing this doubtful association is preferable to making available a possibly unnecessary specific name.

$$
\begin{aligned}
& \text { Medionops cauca } \text { sp. nov. } \\
& \text { urn:Isid:zoobank.org:act:A686E3FD-E3A4-4093-8BCD-6B3DE54C6B50 }
\end{aligned}
$$

Figs 3, 6, 7C

\section{Diagnosis}

Males of M. cauca sp. nov. are readily recognized from other species of Medionops by the embolus strongly angled at the base and slightly sinuous (Figs 3C-D, 7C). Females unknown.

\section{Etymology}

The specific epithet refers to the type locality 'Cauca department'; noun in apposition.

\section{Type material}

\section{Holotype}

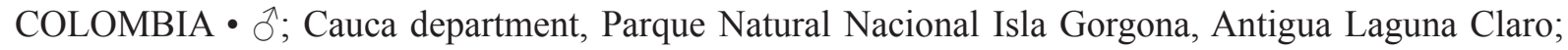
$2^{\circ} 58^{\prime}$ N, $78^{\circ} 11^{\prime}$ W; alt. 70 m; 11 Apr. 2000; R. Duque leg.; IAvH-I 3788.

\section{Description}

Male (holotype, Figs 3A-D, 7C)

MEAsurements. Total length 3.84. Carapace 1.76 long, 1.34 wide. Sternum 1.06 long, 0.86 wide. Legs: I: 3.61; II: 3.43; III: 2.79; IV: 4.15 .

Coloration. Carapace, chelicerae, sternum, palps and legs orange (Fig. 3A); coxae, trochanters and tarsi lighter. Endites and labium light orange (Fig. 3B). Abdomen dorsally dark gray with dorsal pattern formed by five whitish gray chevron stripes, medially joined by thin longitudinal band, and laterally extended as thin stripes; ventrally yellowish (Fig. 3A-B).

Legs And PaLPs. Crista unnoticeable; gladius with common nopine shape. Palp with spherical oval tegulum and slightly sinuous embolus longer than cymbium and strongly angled at base (Figs 3C-D, 7C), with acuminate tip and rounded opening. 


\section{Female}

Unknown.
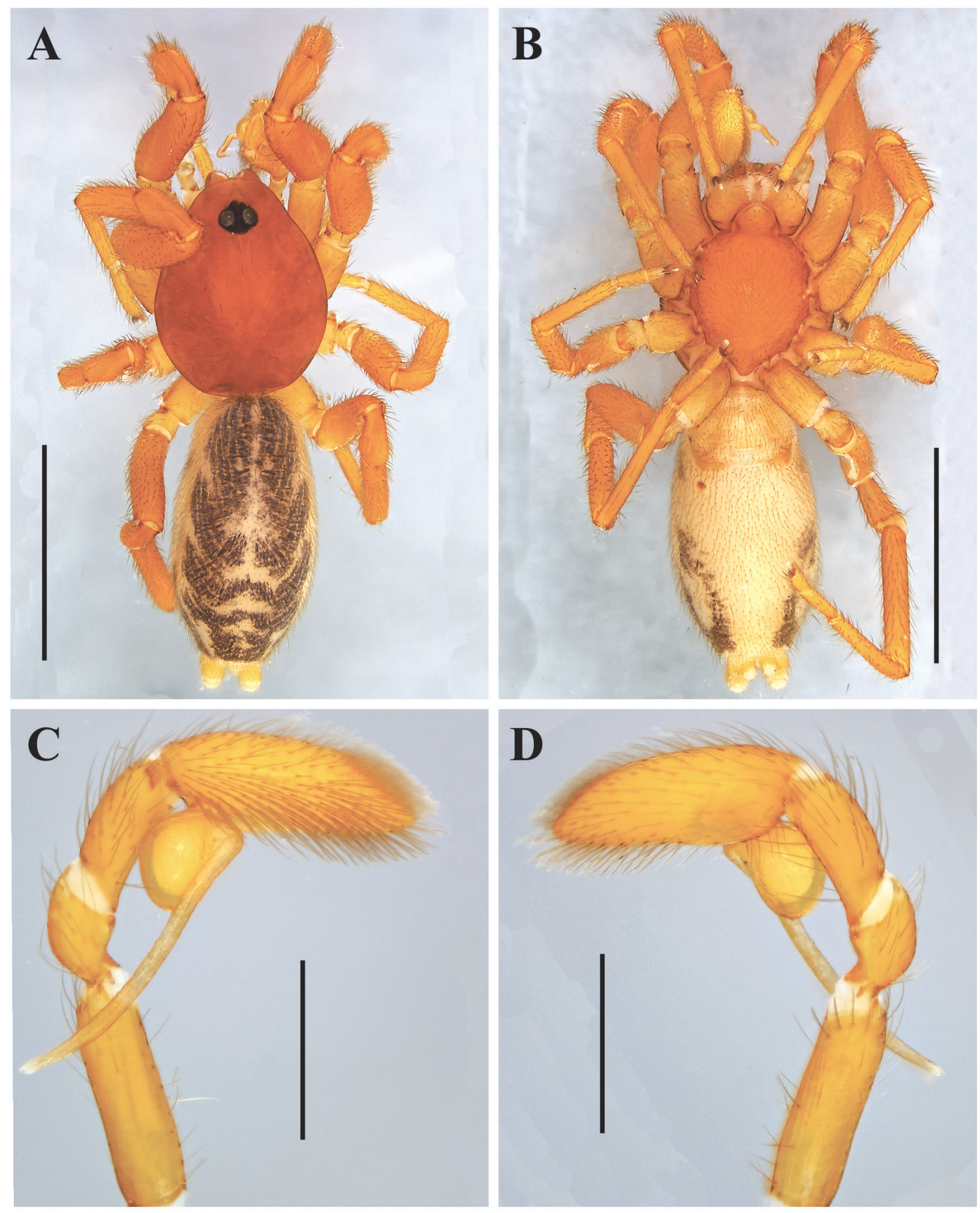

Fig. 3. Medionops cauca sp. nov., holotype, đ̊ (IAvH-I 3788). A. Habitus, dorsal view. B. Habitus, ventral view. C. Left palp, retrolateral view. D. Left palp, prolateral view. Scale bars: A-B $=1.5 \mathrm{~mm}$; $\mathrm{C}-\mathrm{D}=0.5 \mathrm{~mm}$. 


\section{Distribution}

Known only from the type locality in Colombia (Fig. 6).

Medionops luiscarlosi sp. nov.

urn:lsid:zoobank.org:act:96AC990B-8993-478A-A4FD-2BEE997C0347

Figs 4, 6, 7D

\section{Diagnosis}

Males resemble those of $M$. santarosa sp. nov. in having a similar copulatory bulb shape, but can be distinguished by the embolus length more than $3 \times$ the maximum tegular width, with pointed tip (Figs 4E-F, 7D) (shorter, with truncated tip in M. santarosa sp. nov., Figs 5C-D, 7E). Females are distinguished from those of all other species by the flat median concavity on the receptaculum (Fig. 4H).

\section{Etymology}

The specific name is a patronym in honor of Luis Carlos Gutierrez, an unforgettable professor from the Universidad del Atlántico in Colombia who passed away in 2021.

\section{Type material}

\section{Holotype}

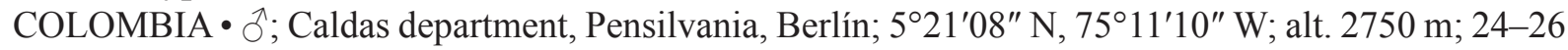
Jul. 2004; E. González and L. Arango leg.; IAvH-I 3361.

\section{Paratypes}

COLOMBIA • 1 đ ; Caldas department, Pensilvania, Finca La Cabaña; $5^{\circ} 22^{\prime} 05^{\prime \prime} \mathrm{N}, 75^{\circ} 10^{\prime} 12^{\prime \prime} \mathrm{W}$; alt. 2650 m; 30 Jul.-Aug. 2004; E. González, L. Arango and J. Montes leg.; IAvH-I 3352 • 1 P; same collection data as for preceding; IAvH-I 3772.

\section{Description}

Male (holotype, Figs 4A-B, E-F, 7D)

Measurements. Total length 3.65. Carapace 1.60 long, 1.21 wide. Sternum 0.98 long, 0.81 wide. Legs: I: 3.68; II: 3.45; III: 2.89; IV: 3.84 .

Coloration. Carapace, chelicerae, palps and legs orange (Fig. 4A); coxae and trochanters lighter (Fig. 4B). Endites, labium and sternum light orange (Fig. 4B). Abdomen dorsally with dorsal pattern of five small, thin, whitish gray chevron stripes, not extending laterally (Fig. 4A); ventrally yellowish gray (Fig. 4B).

LEGS AND PALPS. Crista unnoticeable; gladius with common nopine shape. Palps with spherical tegulum with small projection on posterior side, embolus length more than $3 \times$ the maximum width of tegulum, with pointed tip (Figs 4E-F, 7D), tip of embolus slightly curved and sharp, with small opening.

Female (paratype, Fig. 4C-D, G-H)

Measurements. Total length 4.49. Carapace 1.92 long, 1.42 wide. Sternum 1.10 long, 0.85 wide. Legs: I: 4.13; II: 3.82; III: 3.31; IV: 4.53.

Coloration. As in male (Fig. 4C-D).

LEGS AND PALPS. Crista and gladius as in male. External genitalia with white triangular area below genital opening (Fig. 4G), internal genitalia with flat median concavity on receptaculum (Fig. 4H). 

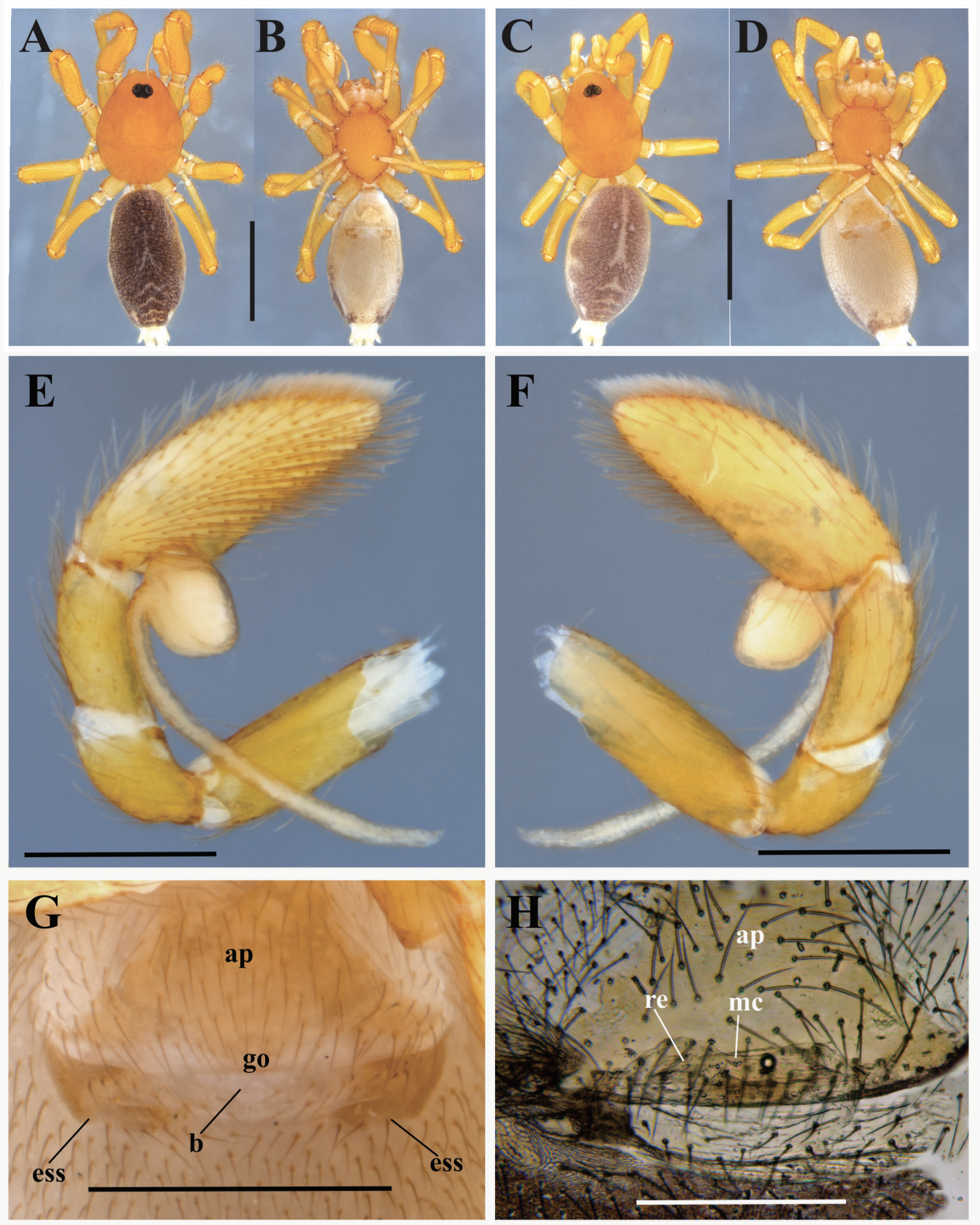

Fig. 4. Medionops luiscarlosi sp. nov. A-B, E-F. Holotype, ô (IAvH-I 3361). C-D, G-H. Paratype, $q$ (IAvH-I 3772). A. Habitus, dorsal view. B. Habitus, ventral view. C. Habitus, dorsal view. D. Habitus, ventral view. E. Left palp, retrolateral view. F. Left palp, prolateral view. G. External genitalia, ventral view. H. Internal genitalia, dorsal view. Scale bars: $A-D=1.5 \mathrm{~mm}$; E-F $=0.7 \mathrm{~mm}$; $\mathrm{G}=0.5 \mathrm{~mm}$; $\mathrm{H}=0.2 \mathrm{~mm}$. Abbreviations: $\mathrm{p}=$ anterior plate; $\mathrm{b}=$ area below genital opening; ess = external sclerotization around spiracles; go $=$ genital opening; $\mathrm{re}=$ receptaculum; $\mathrm{mc}=$ median concavity. 


\section{Variation}

Males $(n=2)$ : total length: $3.35-3.65$; carapace length: $1.60-1.72$.

\section{Distribution}

Known from two localities in Caldas department, Colombia (Fig. 6).

\section{Remark}

All type specimens were collected with pitfall traps.

Medionops santarosa sp. nov. urn:1sid:zoobank.org:act:41140901-0BFC-4DE2-B12F-9BABADD708A5

Figs 5-6, 7E

\section{Diagnosis}

Males resemble those of $M$. luiscarlosi sp. nov. in having a similar copulatory bulb shape but can be distinguished by the embolus length less than $3 \times$ the maximum width of the tegulum, with truncated tip (Figs 5C-D, 7E) (larger, with pointed tip in M. luiscarlosi, Figs 4E-F, 7D). Females unknown.

\section{Etymology}

The specific epithet refers to the type locality 'Santa Rosa de Cabal'; noun in apposition.

\section{Type material}

\section{Holotype}

COLOMBIA • O $^{\text {; }}$ Risaralda department, Parque Municipal Natural Campo Alegre, Santa Rosa de Cabal, Vereda La Linda, Finca La Granja; 452'26" N, 75³1'21" W; alt. 2490-2659 m; 26-28 Fev. 2004; A. Pulido and Y. Martínez leg.; IAvH-I 3362.

\section{Paratypes}

COLOMBIA $\bullet 1$; same collection data as for holotype; IAvH-I $3371 \bullet 1$; same collection data as for holotype; IAvH-I 3372.

\section{Description}

\section{Male (holotype, Figs 5A-D, 7E)}

Measurements. Total length 4.31. Carapace 1.83 long, 1.38 wide. Sternum 1.10 long, 0.85 wide. Legs: I: 4.09; II: 3.75; III: 3.31; IV: 4.81.

Coloration. Carapace, chelicerae, sternum, labium and endites reddish (Fig. 5A). Palps and legs light orange (Fig. 5B). Abdomen dorsally dark gray, with dorsal pattern of five small, thin, whitish gray chevron stripes, not extending laterally (Fig. 5A); ventrally yellowish gray (Fig. 5B).

Legs AND PALPS. Crista unnoticeable; gladius with the common nopine shape. Palp with spherical tegulum; embolus length less than $3 \times$ the maximum width of the tegulum, with truncated tip (Figs $5 \mathrm{C}-$ $\mathrm{D}, 7 \mathrm{E})$ and rounded opening.

\section{Female}

Unknown. 


\section{Variation}

Males ( $\mathrm{n}=3)$ : total length: $3.74-4.31$; carapace length: $1.73-1.83$.
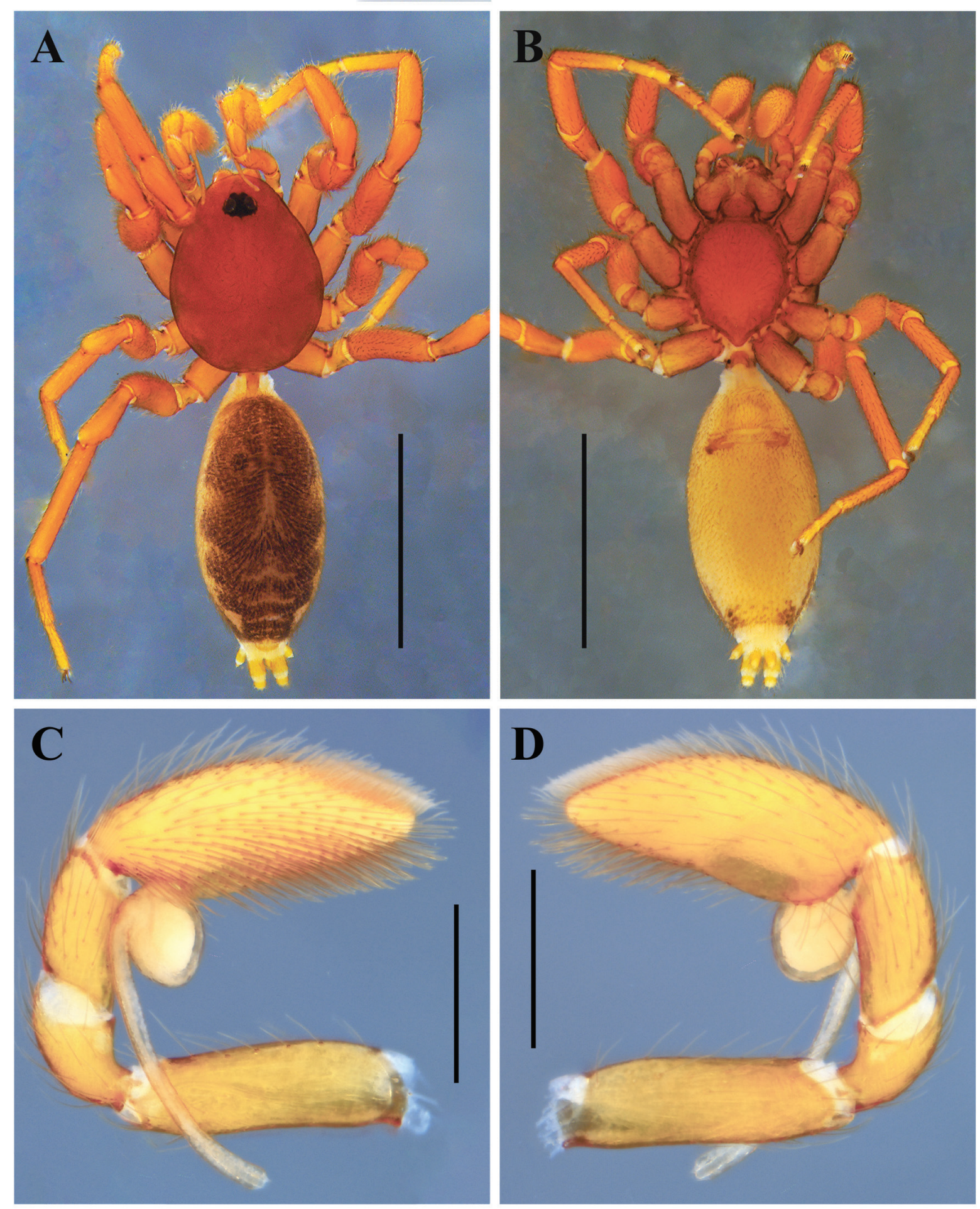

Fig. 5. Medionops santarosa sp. nov., holotype, đ̊ (IAvH-I 3362). A. Habitus, dorsal view. B. Habitus, ventral view. C. Left palp, retrolateral view. D. Left palp, prolateral view. Scale bars: A-B =1.5 mm; $\mathrm{C}-\mathrm{D}=0.5 \mathrm{~mm}$. 


\section{Distribution}

Known only from the type locality in Colombia (Fig. 6).

\section{Discussion}

The present study increases from one to five the number of Colombian Medionops species recorded. All these species are known from only a few localities within the country. Among the nopines, Medionops is one of the few genera presenting all three membranous structures of the pretarsal morphology (crista, gladius and arolium) that appear in members of this subfamily (Sánchez-Ruiz \& Brescovit 2018). These three membranous structures have been known since Keyserling (1877), who was the first to detect them; however their characteristics remained little studied until Sánchez-Ruiz \& Brescovit (2017) standardized their terminologies. The arolium is present only in Nops, Nopsides and Medionops, while the adhesive structures crista and gladius are more common within the nopines. Nyetnops is the only nopine lineage that does not have any of these three structures (Platnick \& Lise 2007). The arolium is evolutionarily related to the elongated unpaired claw, since the unpaired claws became elongated to shelter an enlarged arolium (Sánchez-Ruiz \& Brescovit 2018). However, Nops species are characterized by a very short or reduced arolium, yet the anterior unpaired claws are elongated in all species, and only in a few species are the posterior unpaired claws not elongated. Conversely, Medionops and Nopsides are characterized by a large arolium and an elongated unpaired claw (Sánchez-Ruiz \& Brescovit 2018). Generally, the gladius is homogeneous in size and shape in all lineages that present this structure. Within the nopines with gladius, Medionops is the only genus with at least one species lacking this structure (M. murici Sánchez-Ruiz \& Brescovit, 2017); coincidentally, the crista is also absent in this Brazilian species. This would be the first documented instance of gladius and crista loss within a nopine genus. The crista is also

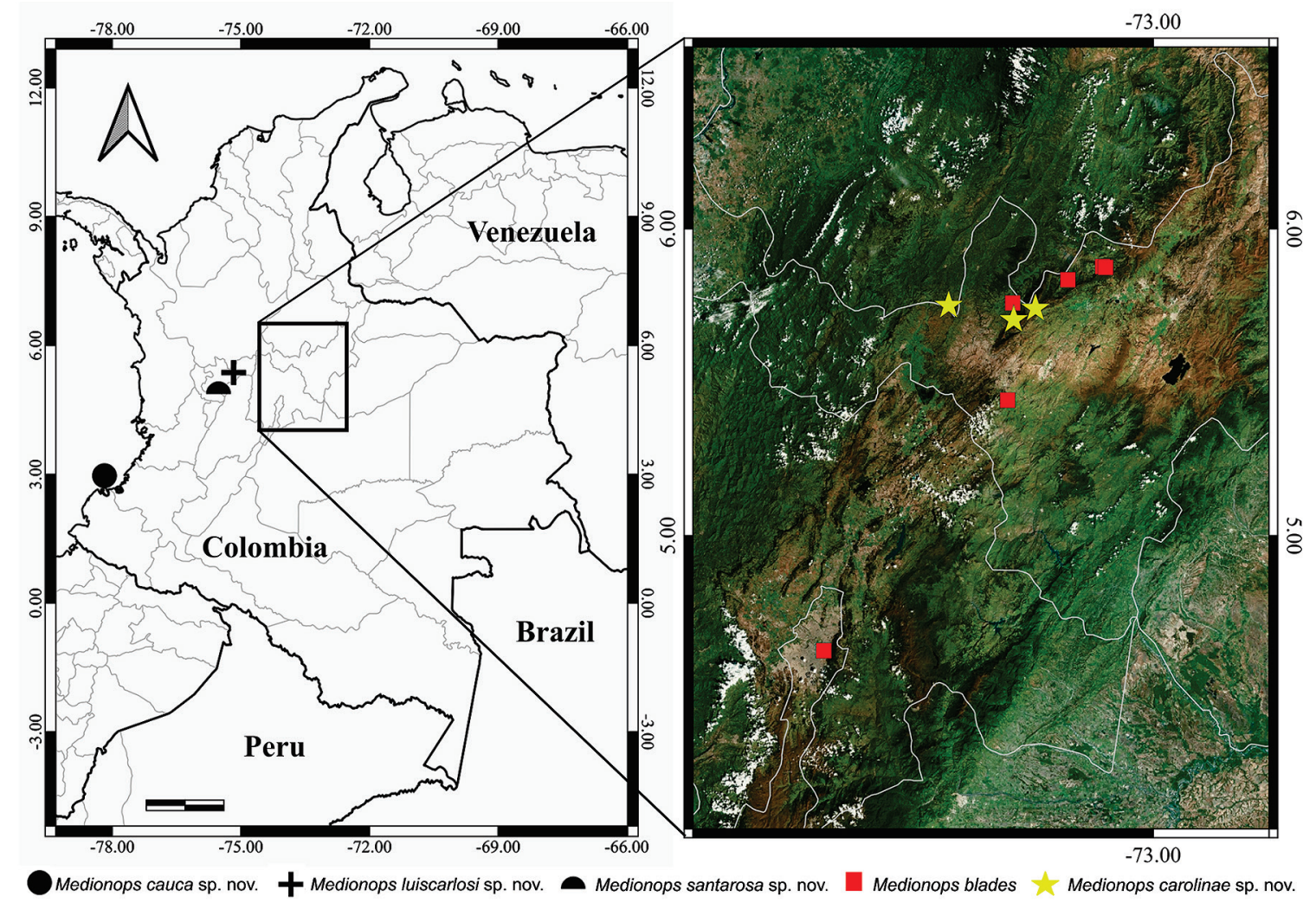

Fig. 6. Distribution map of Colombian species of Medionops Sánchez-Ruiz \& Brescovit, 2017. 
fairly homogeneous among genera, but Medionops again diverges from that pattern, presenting diverse conformations of crista shape and size across species. This genus is generally characterized by a very short crista, but it's unnoticeable in M. ramirezi Sánchez-Ruiz \& Brescovit 2017 and completely absent
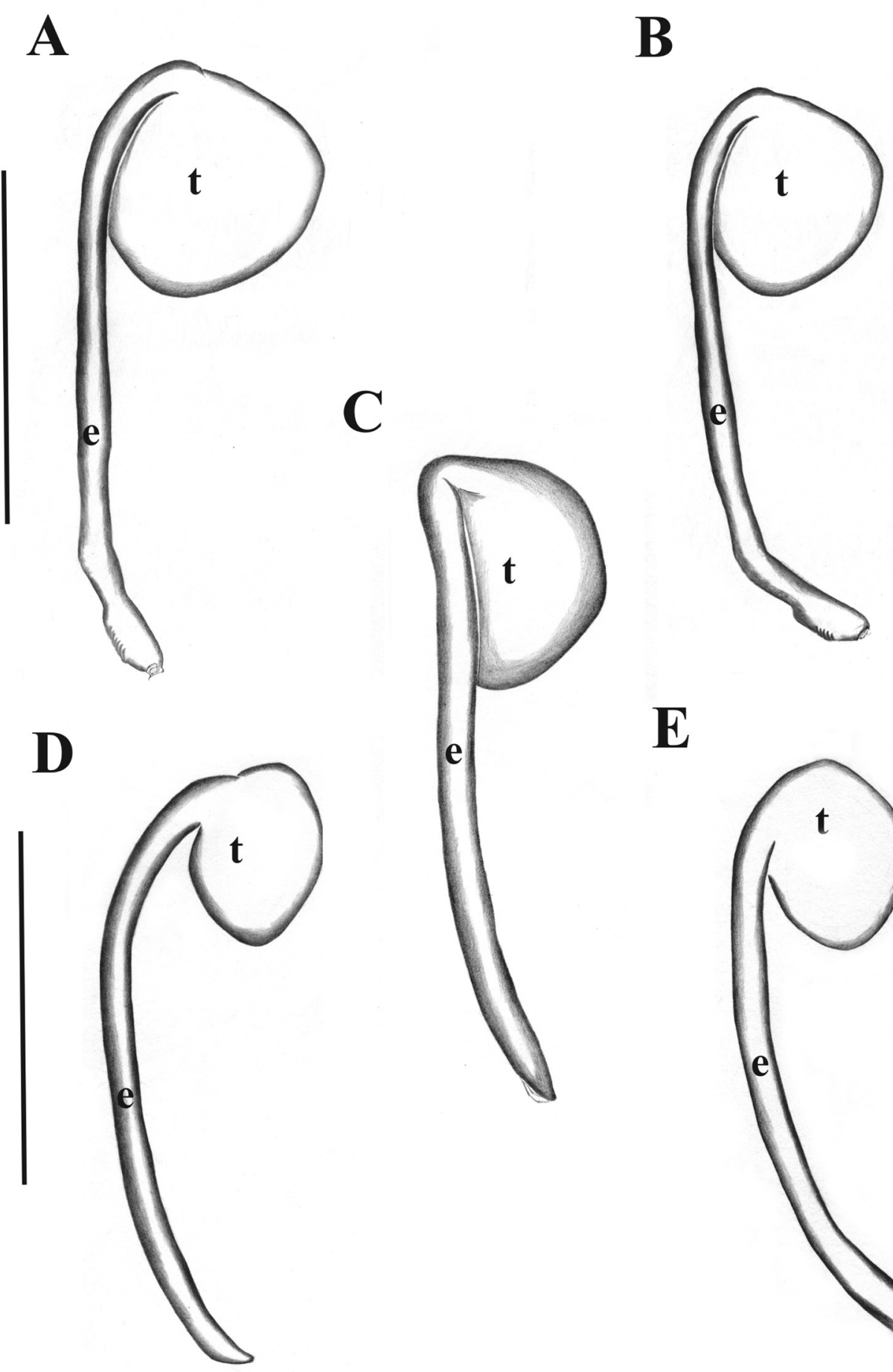

$\mathbf{E}$

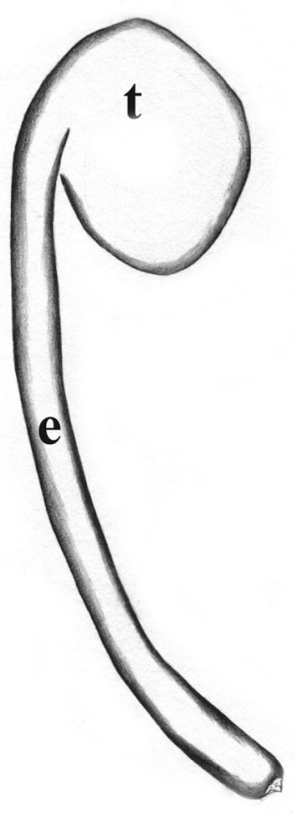

Fig. 7. Drawings of the male copulatory bulbs (retrolateral view) in Colombian species of Medionops Sánchez-Ruiz \& Brescovit, 2017. A. M. blades Sánchez-Ruiz \& Brescovit, 2017. B. M. carolinae sp. nov. C. M. cauca sp. nov. D. M. luiscarlosi sp. nov. E. M. santarosa sp. nov. Scale bars $=0.5 \mathrm{~mm}$. Abbreviations: $\mathrm{e}=$ embolus; $\mathrm{t}=$ tegulum. 
in M. claudiae Sánchez-Ruiz \& Brescovit, 2017 and M. murici Sánchez-Ruiz \& Brescovit, 2017. The Colombian species herein addressed, except for M. blades, present an unnoticeable crista. According to the Nopinae hypothesis proposed by Sánchez-Ruiz \& Brescovit (2018), the crista, gladius and arolium seem to be membranous leg structures that could appear and disappear more easily than other structures.
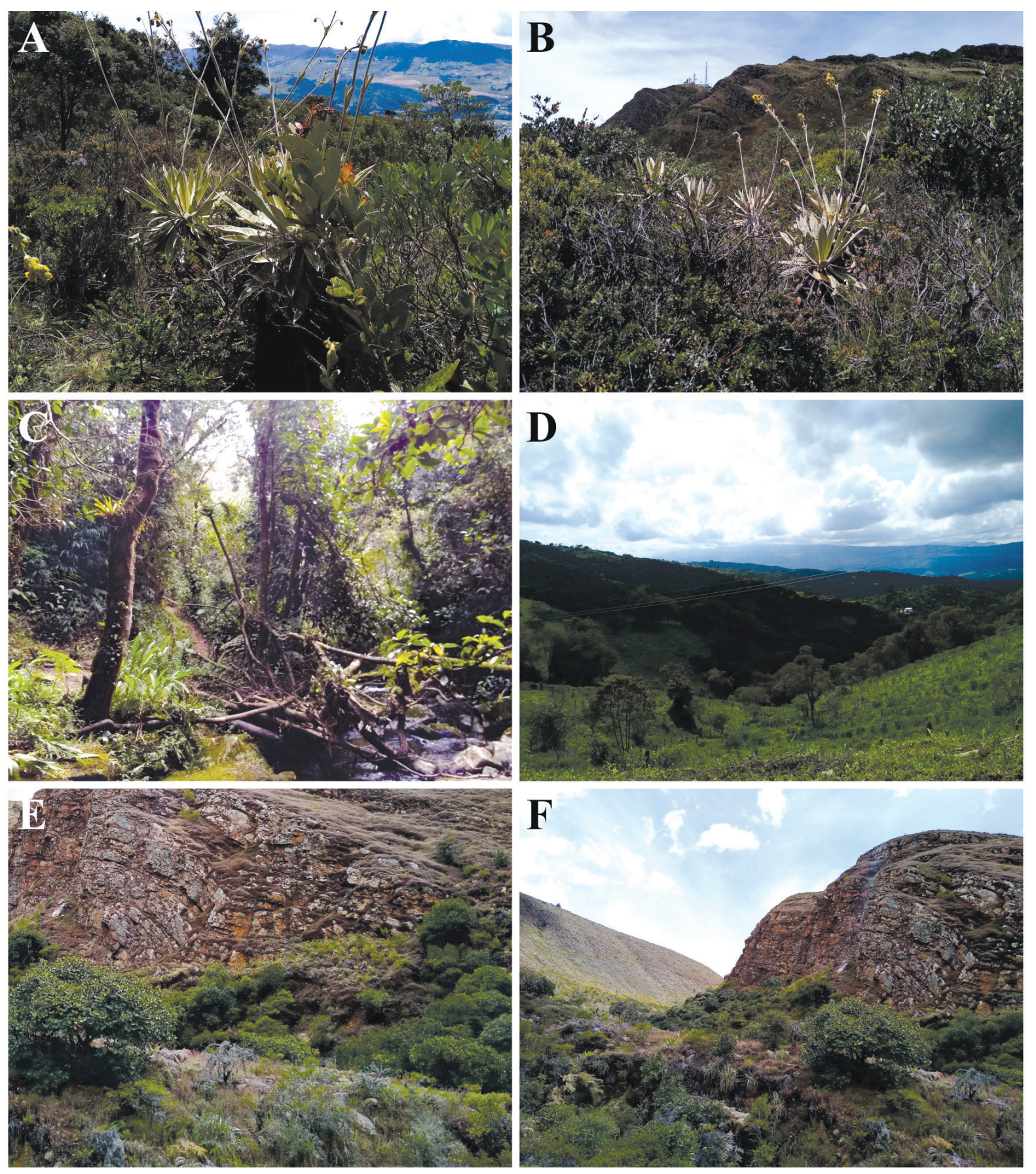

Fig. 8. Habitats of Colombian species of Medionops Sánchez-Ruiz \& Brescovit, 2017. A-B. Type locality of M. blades Sánchez-Ruiz \& Brescovit, 2017, Páramo de Monserrate, Cundimarca department, Colombia. C-D. Type locality of M. carolinae sp. nov., Sutamarchán, Boyacá department, Colombia. E-F. Habitat of female paratype (IAvH-I 3771) of M. carolinae sp. nov., Sector Carrizal, Santuario de Flora y Fauna Iguaque, Boyacá department, Colombia. 
Although the presence and shape of these membranous structures may vary interspecifically in Medionops, intraspecific variation is not common in the genus. As far as we know, detectable morphological variation between populations is present only in M. blades, specifically in the male palpal morphology and the female external genitalia. The populations from Boyacá department have the embolus tip somewhat more curved than those from Cundinamarca department, where the holotype comes from. In females, the area under the genital opening is narrower and more sclerotized in the populations from Boyacá than in those from Cundinamarca department, but the internal receptaculum is very similar in both populations.

On the other hand, M. blades appears to be close to M. carolinae sp. nov. and M. cesari (Dupérré, 2014). The males of these three species have a similar copulatory bulb shape with an oval tegulum and an elongated embolus curved at the tip. However, these species are distinguished by some diagnostic characteristics that suggest a close relationship between the members of $M$. carolinae sp. nov. and M. cesari. Both species have the tegulum $1 / 3$ as long as the cymbium length (larger in M. blades) and an accentuated curvature at the embolus tip (straighter in M. blades). However, the morphology of the emboli tips, both in M. carolinae sp. nov. and in the two known populations of M. blades, is quite similar. In that regard, the several blade-shaped embolar projections, which were diagnostic for members of $M$. blades, are also present in M. carolinae sp. nov.

Considering the variations of both known populations of $M$. blades and their similarities with M. carolinae sp. nov. and M. cesari, the hypothesis that M. blades represents a complex of closely related species cannot be dismissed with the available evidence. We hope soon to be able to obtain more specimens from other localities from Colombia and Ecuador to test this hypothesis with both molecular and additional morphological studies.

\section{Acknowledgments}

We are grateful with Jhon. C. Neita and Carolina Gómez from the Instituto Alexander Von Humboldt for allowing us to revise the material herein referenced. Cristián Casas helped with some of the first line drawings of the male copulatory bulbs. We also thank Rudy Jocque, Ingi Agnarsson and two anonymous reviewers for helpful comments and suggestions on the submitted version of this study. This paper was supported by Programa de Capacitação Institucional (MCTI/MPEG/CNPq 444338/2018-7 process), CNPq grant 302013/2021-0 to ASR and CNPq grant 304965/2012-0 to ABB. We also acknowledge a grant from the Convocatoria para el Fortalecimento de las Instituciones de Educación Superior (Convocatoria 890) from the Science Ministry of Colombia to LM.

\section{References}

Álvarez-Padilla F. \& Hormiga G. 2008. A protocol for digesting internal soft tissues and mounting spiders for scanning electron microscopy. Journal of Arachnology 35: 538-542. https://doi.org/10.1636/Sh06-55.1

García L.F., Viera C. \& Pekár S. 2018. Comparison of the capture efficiency, prey processing, and nutrient extraction in a generalist and a specialist spider predator. The Science of Nature 105 (3): 1-10. https://doi.org/10.1007/s00114-018-1555-z

Keyserling E. 1877. Amerikanische Spinnenarten aus den Familien der Pholcoidae, Scytodoidae und Dysderoidae. Verhandlungen der Kaiserlich-Königlichen Zoologisch-Botanischen Gesellschaft in Wien 27: 205-234.

Petrunkevitch A. 1939. Catalogue of American spiders. Part one. Transactions of the Connecticut Academy of Arts and Sciences 33: 133-338. 
Platnick N.I. 1995. A revision of the spider genus Orthonops (Araneae, Caponiidae). American Museum Novitates 3150: 1-18. Available from https://digitallibrary.amnh.org/handle/2246/3674 [accessed 17 Sep. 2021].

Platnick N.I. \& Lise A.A. 2007. On Nyetnops, a new genus of the spider subfamily Nopinae (Araneae, Caponiidae) from Brazil. American Museum Novitates, 3595: 1-9. https://doi.org/10.1206/0003-0082(2007)3595[1:ONANGO]2.0.CO;2

QGIS Development Team 2021. QGIS Geographic Information System. Ver. 3.18.3. Open Source Geospatial Foundation. Available from https://qgis.org [accessed 17 May 2021].

Sánchez-Ruiz A. \& Brescovit A.D. 2017. A new genus with seven species of the subfamily Nopinae (Araneae, Caponiidae) from the Neotropical region. Zootaxa 4291 (1): 117-143. https://doi.org/10.11646/zootaxa.4291.1.7

Sánchez-Ruiz A. \& Brescovit A.D. 2018. A revision of the Neotropical spider genus Nops MacLeay (Araneae: Caponiidae) with the first phylogenetic hypothesis for the Nopinae genera. Zootaxa 4427 (1): 1-121. https://doi.org/10.11646/zootaxa.4427.1.1

Sánchez-Ruiz A, Brescovit A.D. \& Alayón G. 2015. Four new caponiids species (Araneae, Caponiidae) from the West Indies and redescription of Nops blandus (Bryant). Zootaxa 3972 (1): 43-64.

https://doi.org/10.11646/zootaxa.3972.1.3

Sánchez-Ruiz A., Brescovit A.D. \& Bonaldo A.B. 2020. Revision of the spider genus Nyetnops Platnick \& Lise (Araneae: Caponiidae) with proposition of the new genus Nopsma, from Central and South America. Zootaxa 4751 (3): 461-486. https://doi.org/10.11646/zootaxa.4751.3.3

Teruel R. \& Sánchez-Ruiz A. 2000. Nota sobre la depredación de un escorpión (Scorpiones: Buthidae) sobre una araña (Araneae: Caponiidae). In: Maceira D. \& Fong A. (eds) Biodiversidad de Cuba Oriental 4: 82-83. Editorial Academia de Ciencias de Cuba, La Habana.

Manuscript received: 12 June 2021

Manuscript accepted: 24 August 2021

Published on: 29 September 2021

Topic editor: Rudy Jocqué

Desk editor: Eva-Maria Levermann

Printed versions of all papers are also deposited in the libraries of the institutes that are members of the EJT consortium: Muséum national d'histoire naturelle, Paris, France; Meise Botanic Garden, Belgium; Royal Museum for Central Africa, Tervuren, Belgium; Royal Belgian Institute of Natural Sciences, Brussels, Belgium; Natural History Museum of Denmark, Copenhagen, Denmark; Naturalis Biodiversity Center, Leiden, the Netherlands; Museo Nacional de Ciencias Naturales-CSIC, Madrid, Spain; Real Jardín Botánico de Madrid CSIC, Spain; Zoological Research Museum Alexander Koenig, Bonn, Germany; National Museum, Prague, Czech Republic. 